\title{
Communicating Environmental and Ethical Performance: A Longitudinal Analysis of Annual Reports from 1998-2009
}

\begin{abstract}
Along with the publics' increased demand for businesses to operate responsibly, more and more companies proactively publish their CSR-related principles and activities. A growing body of research is dedicated to the analysis of patterns in self-reported CSR performances; these studies use annual reports as a proxy for the social or environmental activities of the companies. Integrating qualitative and quantitative approaches, the aims of this paper are twofold: First, on the basis of content analysis, we examine categories of CSR-related communication that are in a second step used in a longitudinal perspective spanning twelve years, to compare how CSR motives and activities have changed over time.
\end{abstract}

\section{Introduction}

Over the last decades, corporate social responsibility (CSR) has received a large amount of attention in managerial research and practice. In the context of ecological and social challenges, such as global warming, child labour, the world financial crisis, or the Deepwater Horizon oil spill, the impact that companies have on the environment and on society is becoming increasingly apparent. Along with this, empirical results indicate that consumers are influenced by CSR initiatives of businesses if they are aware of them (e.g., Pomering/Dolnicar 2007; Vlachos et al. 2009). As a response to the growing awareness of and concern about social and environmental issues, more and more companies are proactively publishing their CSR-related principles and activities. As one of the most important sources of information on corporate activities, corporate annual reports include corporations' self- reported CSR performances and provide a means of determining the quality of the corporations' commitment to CSR (Macleod 2001). A growing body of research is dedicated to the analysis of patterns in or motivations for companies' voluntary social or environmental disclosures (Brammer/Pavelin 2008); these studies use annual reports as a proxy for the social or environmental activities of the companies (Milne/Adler 1999). Past research analysing annual reports or CSR reports in various national contexts (e.g., Abbott/Monsen 1979; Gray et al. 1995; Campbell 2004) has relied mainly on simple measures, such as word and page counts of reports (Chen/Bouvain 2009), and has mostly failed to provide a category scheme that goes beyond CSR-related activities. Therefore, in this paper, we seek to overcome some of these deficiencies by using a combination of quantitative and qualitative approaches. Our empirical examination aims at CSR from a company's and not a customer's point of view (e.g., Singh et al. 2008; Vlachos et al. 2009) and encompasses a sample including the annual reports of all German DAX-30 companies from 1998 to 2009. We build upon and extend the insights from Cormier et al. (2005) and Beck et al. (2010), who analysed annual reports with reference to environmental disclosure by German companies. In our study, we focus not only on corporate environmental disclosures but also on corporate social disclosures published in the companies' annual reports. Our research aims are twofold. First, on the basis of content analysis, we examine categories of CSR-related communication. Second, we then use

\footnotetext{
* Thomas Kilian

Institute for Management

University of Koblenz-Landau

Universitätsstrasse 1

56070 Koblenz

Germany

kilian@uni-koblenz.de
}

\author{
* Nadine Hennigs \\ Institute for Marketing and Management \\ Leibniz University Hannover \\ Königsworther Platz 1 \\ 30167 Hannover \\ Germany \\ nadine.hennigs@m2.uni-hannover.de
}


these categories in a longitudinal perspective spanning twelve years to compare how motives to pursue CSR and CSR-related activities have changed over time.

\section{Theoretical background}

\subsection{The importance of CSR reporting}

To promote an international framework for corporate social responsibility in managerial practice, the European Commission (2001: 6) describes CSR as "a concept whereby companies integrate social and environmental concerns in their business operations and in their interaction with their stakeholders on a voluntary basis".

From a managerial point of view, Carroll (1979) describes the social responsibility of companies as a pyramid with four main layers: a) economic responsibility and the management of the core business to provide jobs, produce products and services, and operate profitably; b) legal responsibilities, as goods and services have to comply to different judicial regulations; c) ethical responsibilities, which are based on the prevailing values and standards of a society; and d) philanthropic responsibility in the form of voluntary actions of the company desired by society. To be considered socially responsible and accepted by stakeholders, all of the layers of responsibility within the pyramid are of importance, and "CSR should be framed in such a way that entire business responsibilities are embraced" (Carroll 1991: 4).

Along with the publics' increased demand for businesses to operate responsibly, stakeholders want to be informed about what their company does correctly and what it does incorrectly (Pomering/Dolnicar 2009). According to legitimacy theory, firms act legitimately if they comply with the values of the society in which they are embedded; if they do not comply, their legitimacy is removed by society (Schocker/Sethi 1974; Dowling/Pfeffer 1975). To remain legitimate, companies communicate topics that concern society, such as activities in CSR. However, beyond legitimisation, CSR reporting is believed to promote companies' reputation and foster competitive advantages (Kuruppu/Milne 2010). Studies have shown that CSR has an overall positive influence on a firm's financial performance (Orlitzky et al. 2003), can build brand equity (Hoeffler/Keller 2002) and can foster competitive advantages (Porter/Kramer 2002), customer loyalty and other positive post-purchase outcomes (Bhattacharya/Sen 2003). Therefore, the rationale for the positive effects of CSR is straightforward: customers are more likely to be positively attracted to products or services provided by a firm that is acting socially responsible, investors are more likely to buy their stocks, and, among other factors, potential employees are more likely to apply for jobs. However, communicating CSR initiatives may be problematic (Pomering/Dolnicar 2007), as consumers tend to be sceptical of companies that advertise their 'good deeds' (Pomering/Dolnicar 2007; Drumwright 1994). Therefore, a main challenge of stakeholders' acceptance of CSR reporting is that CSR messages are proven by corresponding corporate activities.

\section{Conceptual framework}

For the purposes of this paper, following a comprehensive understanding of CSR as a strategic management approach, we conceptualise CSR as illustrated in Figure 1. This framework represents our definition of CSR from a company's point of view, encompassing CSR-related motives and activities and its effects on outcomes such as the company's financial performance and corporate reputation, which is moderated by firm characteristics and situational conditions. The elements of this framework can be described as follows: 


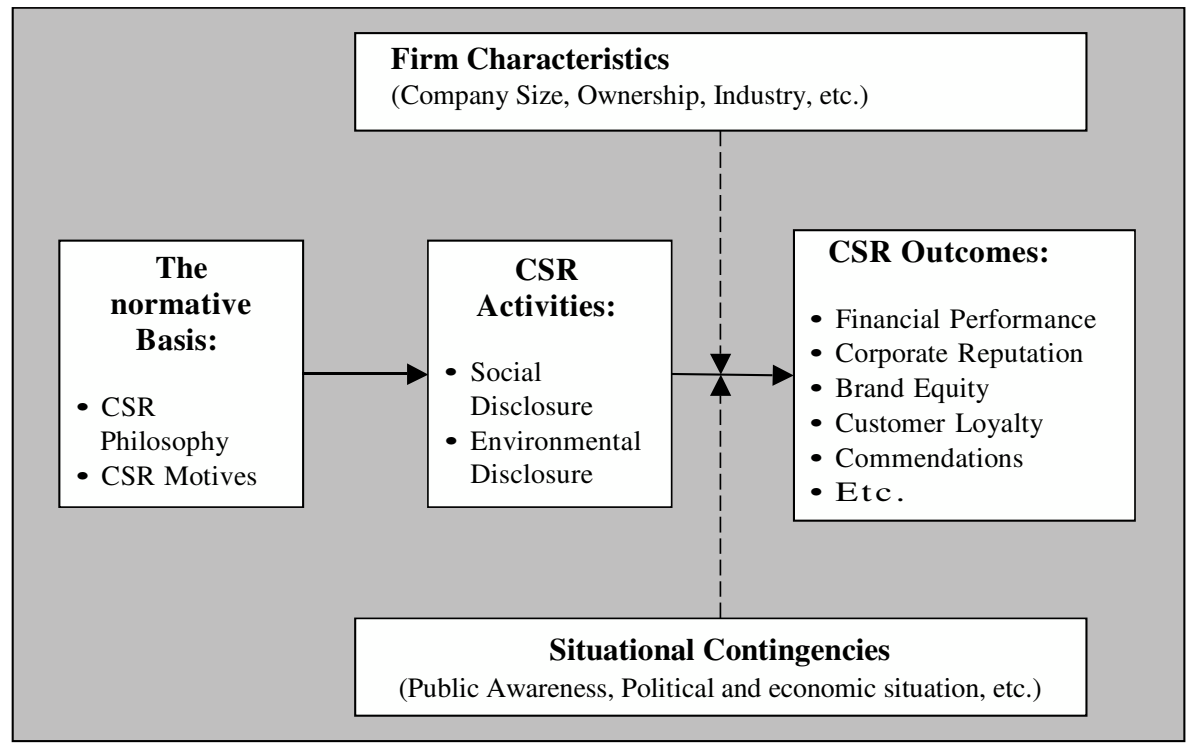

Figure 1. The Conceptual Model

\subsection{The normative basis: CSR-related philosophy and motives}

A normative environment that encourages socially responsible behaviour will affect corporate responses by pressuring them into engaging in and reporting on their CSR activities (Chen/Bouvain, 2009). If companies act on the basis of the principle of 'doing good', this behaviour will be spread in the organisation and thus provide a basis for CSR practices among both managers and employees (Jones 1995). Therefore, CSR should be defined within the normative framework of underlying corporate philosophical principles and related motives.

In accordance with Carroll (1979), researchers conceptualise the concept of CSR and components of a CSR-related philosophy along economical, legal and philanthropic dimensions (e.g., Gupta/Pirsch 2008; Jamali/Mirshak 2007); some authors specify the ethical dimension using terms like 'social', 'stakeholder' or 'ecological' (e.g., Ibrahim et al. 2003; Amaeshi et al. 2006). Based on CSR-motives (e.g., Siegel/Vitaliano 2007; Lougee/Wallace 2008; Idowu/Papasolomou 2007; Anselmsson/Johansson 2007) as the reasons why companies engage in CSRrelated activities, five motives have been identified: economical, moral, social, ecological, and legal motives. For the purposes of our study, we follow Maignan/Ralston (2002), who distinguish between three main motives for CSR: 1) value-driven motives, where CSR is understood as a part of corporate culture or as the expression of the company's values; 2) stakeholder-driven motives, where CSR is viewed as a reaction to the pressure and control of one or more stakeholder groups; 3) performance-driven motives, where CSR is part of the company's economical mission and a means of increasing the financial performance and competitive position.

\subsection{CSR-related activities: social and environmental disclosure in annual reports}

As shown in Table 1, a wide field in accounting research is dedicated to the analysis of annual reports with reference to social or environmental disclosure. In general, these studies distinguish between different categories of social or environmental disclosure, such as environmental, employee and ethical disclosures (Adams et al. 1998), deal with equal opportunity, personnel, community involvement and products (Abbott/Monsen 1979), or the commitment to investors, employees, community, customers, environment and communication (Calabres/Lancioni 2008). 


\begin{tabular}{|c|c|}
\hline $\begin{array}{l}\text { Author/s (year): } \\
\text { research focus }\end{array}$ & Categories of Social or Environmental Disclosure \\
\hline $\begin{array}{l}\text { Ernst and Ernst } \\
\text { (1978) }\end{array}$ & $\begin{array}{l}\text { - Theme (environment, energy, products/consumers, community, employee/human } \\
\text { resources, fair business practices, general/other) } \\
\text { - Evidence (monetary quantification, non-monetary quantification, both monetary and } \\
\text { non-monetary quantification, declaration) }\end{array}$ \\
\hline $\begin{array}{l}\text { Abbott/Monsen } \\
\text { (1979): Social and } \\
\text { Environmental } \\
\text { Disclosure }\end{array}$ & $\begin{array}{l}\text { - Environment } \\
\text { - Equal opportunity } \\
\text { - Personnel } \\
\text { - Community involvement } \\
\text { - Products } \\
\text { - Other }\end{array}$ \\
\hline $\begin{array}{l}\text { Gray et al. (1995): } \\
\text { Social and } \\
\text { Environmental } \\
\text { Disclosure }\end{array}$ & $\begin{array}{l}\text { - Mandatory disclosure (e.g., employment of disabled) } \\
\text { - Voluntary disclosure } \\
\text { - Human resource disclosure } \\
\text { - Environmental disclosure } \\
\text { - Community disclosure }\end{array}$ \\
\hline $\begin{array}{l}\text { Hackston/Milne } \\
\text { (1996): Social and } \\
\text { Environmental } \\
\text { Disclosure }\end{array}$ & $\begin{array}{l}\text { - Physical environment } \\
\text { - Energy } \\
\text { - Human resources } \\
\text { - Products } \\
\text { - Community involvement }\end{array}$ \\
\hline $\begin{array}{l}\text { Adams et al. } \\
\text { (1998) }\end{array}$ & $\begin{array}{l}\text { - Environmental issues } \\
\text { - Employee issues } \\
\text { - Ethical issues } \\
\end{array}$ \\
\hline $\begin{array}{l}\text { Patten (2002): } \\
\text { Environmental } \\
\text { Disclosure }\end{array}$ & $\begin{array}{l}\text { - Environmental regulations } \\
\text { - Firm's processes, facilities, or product innovations relative to the reduction of } \\
\text { environmental degradation. } \\
\text { - Company's concern for the environment } \\
\text { - Company's environmental compliance status } \\
\text { - Capital expenditures for pollution control or abatement } \\
\text { - Projected future capital expenditures for pollution control or abatement } \\
\text { - Operating costs for pollution control or abatement } \\
\text { - Costs for pollution control or abatement }\end{array}$ \\
\hline $\begin{array}{l}\text { Campbell (2004): } \\
\text { Environmental } \\
\text { Disclosure }\end{array}$ & $\begin{array}{l}\text { - Company's attitude } \\
\text { - Environmental impact } \\
\text { - Emissions } \\
\text { - Pollution } \\
\text { - Cleaning up (after pollution) } \\
\text { - Re-landscaping } \\
\text { - Energy efficiency } \\
\end{array}$ \\
\hline $\begin{array}{l}\text { van der Laan } \\
\text { Smith et al. } \\
(2005): \text { Social } \\
\text { disclosure }\end{array}$ & $\begin{array}{l}\text { - Human resources } \\
\text { - Community involvement } \\
\text { - Consumer relations } \\
\text { - Product safety } \\
\text { - Environmental practices } \\
\text { - Stockholder rights }\end{array}$ \\
\hline $\begin{array}{l}\text { Freedman/Patten } \\
(2004) ; \\
\text { Cho/Patten } \\
\text { (2007): } \\
\text { Environmental } \\
\text { Disclosure }\end{array}$ & $\begin{array}{l}\text { Non-Monetary disclosures } \\
\text { - Company's environmental policy or concern for the environment } \\
\text { - Company's pollution control facilities or processes } \\
\text { - Specific (non-hazardous waste-related) environmental regulations or requirements } \\
\text { - Company's being in compliance with environmental regulations. } \\
\text { Monetary disclosures } \\
\text { - Current or past years' capital expenditures for pollution control or abatement } \\
\text { - Projected future capital expenditures for pollution control or abatement } \\
\text { - Current or past years' operating costs for pollution control or abatement } \\
\text { - Projected future operating costs for pollution control or abatement }\end{array}$ \\
\hline $\begin{array}{l}\text { Comier et al. } \\
\text { (2005); Aerts et al. } \\
\text { (2008): }\end{array}$ & $\begin{array}{l}\text { - Environmental expenditures and risks } \\
\text { - Laws and regulations } \\
\text { - Pollution abatement }\end{array}$ \\
\hline
\end{tabular}




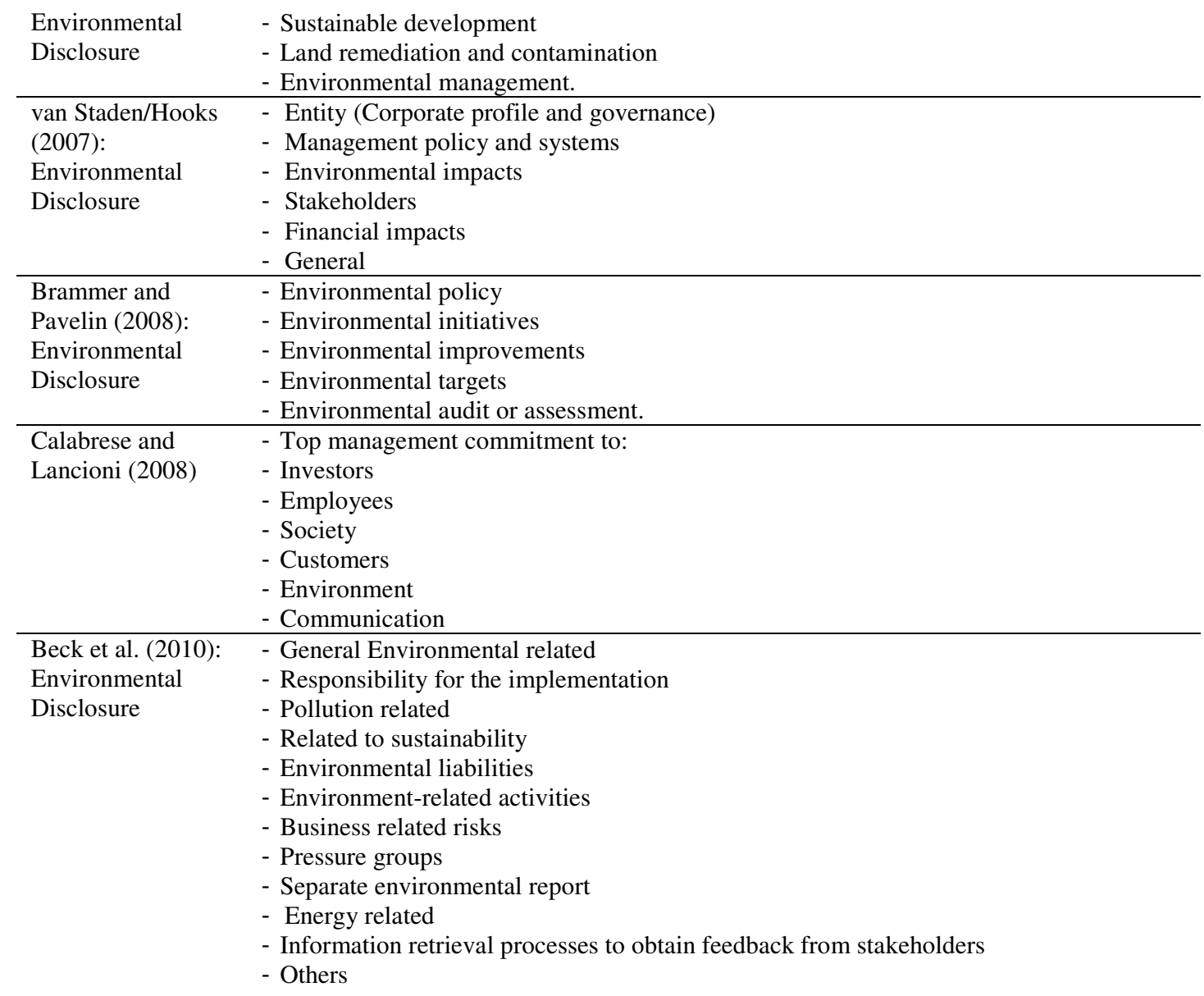

Table 1. Social or Environmental Disclosure in Annual Reports

Approaches using a questionnaire-based methodology to conceptualise CSR differentiate between CSR activities related to a) social and non-social stakeholders, employees, customers, and the government (Turker 2009), b) the workforce, customers, stakeholders, the environment and charity (Pedersen 2009), c) environmental management, employment, supply chain management, the local community, controlling and reporting, and community volunteering (Perrini et al. 2007), or d) employment, the environment, the supply chain, the local community and volunteering, and engagement/human resource management (Russo/Tencati 2009). In sum, the cited studies from accounting research that analyse social or environmental disclosure in annual reports fail to provide a meaningful conceptualisation or profound category scheme (e.g., Abbott/Monsen 1979; Adams et al. 1998; Campbell 2004; Deegan/Gordon 1996; Gray et al. 1995; Ingram/Frazier 1980). Because research has so far been mainly based on content analyses that only count statements of disclosure, there is still a lack of research that attempts to relate the identified codes to the strategic embeddedness of CSR activities referring to motives for disclosure or the CSR-related philosophy.

\subsection{CSR-related outcomes and moderating effects}

A number of studies have analysed CSR activities, corporate environmental and/or social disclosures and have related them to different measures such as financial and environmental performance, stock returns, analysts' forecast accuracy, the effects on potential employees, and a firm's reputation (Aerts et al. 2008; Brammer/Pavelin 2008; Deegan/Gordon 1996; Gray et 
al. 1996; Campbell 2004; Hasseldine et al. 2005; Hope/Pope 2003; Kuruppu/Milne 2010; Balsam et al. 2002; Lee/Hutchinson 2005; Patten 2002; van der Laan Smith et al. 2005). Another performance measure that was found in the reports are commendations, i.e. awards and the inclusion of company stocks in CSR-related stock indices. The impact of social and environmental disclosure on different performance measures was found to be moderated by variables such as characteristics of the companies (e.g., the company's size, its stakeholder or shareholder orientation, environmental sensitivity, the company's ownership structure, its proximity to customers or industry specifics) as well as situational contingencies (e.g., public awareness of CSR, political and economic environment) (Aerts et al. 2008; Brammer/Pavelin 2008; Deegan/Gordon 1996; Gray et al. 1996; Campbell 2004; Hasseldine, et al. 2005; Hope/Pope 2003; Kuruppu/Milne 2010; Balsam et al. 2002; Lee/Hutchinson 2005; Patten 2002; van der Laan Smith et al. 2005).

\section{Methodology}

Understood as information about "organization-society interactions relating to the natural environment, employees, communities and customers" (Gray et al. 1995: 48), CSR reporting in corporate annual reports forms the basis of our study. Annual reports are considered the most important, highly credible source of information on corporate activities and performance in different fields, are sent to all shareholders and are widely recognised, for instance, by financial analysts (Adams et al. 1998; Neu et al. 1998). CSR reporting in annual reports is not practised systematically or in a standardised way by companies and remains voluntary and unaudited (Cromier et al. 2005; Beck et al. 2010). However, it can be expected that environmental and social reporting will be regulated in the mid or long term (e.g., Lee/Hutchinson 2005). Cormier et al. (2005) have noted that German firms' environmental concerns are higher than those in other large European countries; therefore, the German context seems appropriate for the purposes of our study. We analysed annual reports of the DAX-30 (German Stock Index) companies listed on the Frankfurt Stock Exchange. The DAX-30 is the leading stock index in Germany and comprises the 30 largest companies in terms of turnover. The composition of the DAX-30 has not been stable since its introduction in 1988; we thus concentrated on reports from companies represented in the index for most of the time from 1998 to 2009. Even though DAX companies are not representative of the overall German economy, they are leaders of their sectors and influence the whole economy as role models. The companies integrated in our analysis are listed in Table 2. 


\begin{tabular}{|c|c|c|}
\hline Company & Sector & Years \\
\hline Adidas AG & Sporting Goods & 1998-2009 \\
\hline Allianz SE & Insurance & 1998-2009 \\
\hline BASF SE & Chemical & 1998-2009 \\
\hline Bayer AG & Chemical and Pharmaceutical & 1998-2009 \\
\hline BMW AG & Automotive & $1998-2009$ \\
\hline Commerzbank AG & Banking & 1998-2009 \\
\hline Continental AG & Automotive Supplier & 1998-2009 \\
\hline Daimler AG & Automotive & 1998-2009 \\
\hline Deutsche Bank AG & Banking & 1998-2009 \\
\hline Deutsche Boerse AG & Financial Services & $1999-2009$ \\
\hline Deutsche Lufthansa AG & Aviation & $1998-2009$ \\
\hline Deutsche Post AG & Logistics & $1998-2009$ \\
\hline Deutsche Postbank AG & Banking & 1998-2009 \\
\hline Deutsche Telekom & Telecommunication & 1998-2009 \\
\hline E.ON AG & Energy & $2000-2009$ \\
\hline Fresenius Medical Care AG \& Co. KGaA & Medical Engineering & 1998-2009 \\
\hline Henkel KgaA & Consumer Goods & $1998-2009$ \\
\hline Hypo Real & Financial Services & 2003-2009 \\
\hline Infineon Technologies AG & Semiconductor & 2000-2009 \\
\hline Linde AG & Gas and Engineering & $1998-2009$ \\
\hline MAN AG St & Automotive Manufacturer & 1998-2009 \\
\hline Merck KGaA & Chemical and Pharmaceutical & $1998-2009$ \\
\hline METRO AG St & Commerce & 1998-2009 \\
\hline Muenchner Rueck AG & Insurance & 1998-2009 \\
\hline RWE AG & Energy & $1998-2009$ \\
\hline SAP AG & Software & 1998-2009 \\
\hline Siemens AG & $\begin{array}{l}\text { Electronics, Automotive } \\
\text { Supply, Power Plants and } \\
\text { Medical Engineering }\end{array}$ & 1998-2009 \\
\hline ThyssenKrupp AG & Steel and Armaments & $1999-2009$ \\
\hline TUI AG & Tourism & 1998-2009 \\
\hline Volkswagen AG & Automotive & 1998-2009 \\
\hline
\end{tabular}

Table 2. Companies and Annual Reports included in the Study

\section{Data analysis and key findings}

To achieve our research goals, this study uses a mixed qualitative-quantitative approach (Srn$\mathrm{ka}$ and Koeszegi 2007). On the basis of annual reports from German DAX-30 companies from 1998 to 2009 , we conducted a content analysis to quantify the constructs as presented in Figure 1. In the second step, we analysed the data from a longitudinal perspective spanning twelve years, to present how codings have changed over time.

\subsection{Step 1: Content analysis using MAXQDA}

To identify recurring themes in the reports, we used content analysis - a common scientific research method in various disciplines such as psychology, sociology, and politics (e.g., Kassarjian 1977; Krippendorf 2003). All reports were transferred to Rich Text Format, which is 
required by MAXQDA, the analysis program we employed. The coding was done manually, where the defined coding unit was a phrase or a clause. To capture all relevant meanings, in accordance to Beck et al. (2010), we found early on in the coding process that more than one code was found in one sentence and that one code could be spread over several sentences. During the coding process, we adopted a mixed deductive-inductive process, as suggested by Srnka and Koeszegi (2007). Starting with categories, that is, common patterns and themes identified in the literature (philosophy, motives and activities related to CSR), we performed a pretest with 30 randomly chosen annual reports. The initial coding phase had two rounds conducted by two authors, both of whom were experienced in content analysis. To ensure accurate coding, several decision rules were formulated (see Table 4). Finally, both authors agreed on a coding scheme, as shown in Table 3, based on categories that are mutually exclusive and reliable.

\begin{tabular}{|c|c|c|}
\hline Main Category & First Subcategory & Coding Example \\
\hline \multirow[t]{2}{*}{$\begin{array}{l}\text { Stated } \\
\text { Philosophy } \\
\text { towards CSR }\end{array}$} & $\begin{array}{l}\text { Environmental } \\
\text { Responsibility } \\
(223 \text { codings })\end{array}$ & $\begin{array}{l}\text { "Ecological considerations largely determine the corporate activity of the corporations' } \\
\text { enterprises." (TUI 2001) }\end{array}$ \\
\hline & $\begin{array}{l}\text { Social } \\
\text { Responsibility } \\
\text { (185 codings) }\end{array}$ & $\begin{array}{l}\text { "The company sees itself as a part of society and as a 'Good Corporate Citizen', feels } \\
\text { obliged to act responsible." (Bayer 2009) }\end{array}$ \\
\hline \multirow[t]{3}{*}{ CSR Motives } & $\begin{array}{l}\text { Performance-Driven } \\
\text { (94 codings) }\end{array}$ & $\begin{array}{l}\text { "Our key objective is profitable growth." (Allianz 2000) } \\
\text { "For us, entrepreneurial success and social responsibility belong together. "(Daimler } \\
2004)\end{array}$ \\
\hline & $\begin{array}{l}\text { Stakeholder-Driven } \\
\text { (110 codings) }\end{array}$ & $\begin{array}{l}\text { "The MAN group is committed to the stakeholder concept - besides the shareholders' } \\
\text { interests, the interests of our customers, employees, suppliers, creditors and all other } \\
\text { stakeholders are adequately taken into consideration." (MAN 2005) }\end{array}$ \\
\hline & $\begin{array}{l}\text { Value-Driven } \\
\text { (100 codings) }\end{array}$ & $\begin{array}{l}\text { “... is based upon the principle of sustainability and, especially in light of the difficult } \\
\text { times our company faces, adheres to it. We consider sustainable action holistically. This } \\
\text { includes economical standards as well as cultural, social and naturally ecological } \\
\text { aspects." (Münchner Rück 2002) }\end{array}$ \\
\hline \multirow[t]{3}{*}{$\begin{array}{l}\text { CSR-related } \\
\text { Internal } \\
\text { Activities }\end{array}$} & $\begin{array}{l}\text { Organisational } \\
\text { Activities } \\
\text { (701 codings) }\end{array}$ & $\begin{array}{l}\text { "Our Sustainability Council directs the global activities in cooperation with the operative } \\
\text { divisions, the regional and national companies as well as the central functions. "(Henkel } \\
2006 \text { ) } \\
\text { "... worldwide legal compliances, which oblige everyone to adhere to the laws and } \\
\text { regulations." (Bayer 2000) }\end{array}$ \\
\hline & $\begin{array}{l}\text { Products and } \\
\text { Production } \\
\text { (902 codings) }\end{array}$ & $\begin{array}{l}\text { "For newly developed products and procedures, we make sure from the very beginning } \\
\text { that as little energy as possible is used and that the natural resources are preserved." } \\
\text { (ThyssenKrupp 2001) } \\
\text { "We create products that are safe to produce, use, recycle and dispose of." (BASF 2000) }\end{array}$ \\
\hline & $\begin{array}{l}\text { Activities in Human } \\
\text { Resource } \\
\text { Management } \\
(275 \text { codings }) \\
\end{array}$ & $\begin{array}{l}\text { "Hence, we encourage a culture in which everyone can contribute to the success (...) } \\
\text { regardless of nationality, culture, religion, age, sex or skin color." (Infineon 2006) } \\
\text { "In 2002, Infineon has, as an incentive for its employees, launched the ESH-Award." } \\
\text { (Infineon 2002) }\end{array}$ \\
\hline \multirow{2}{*}{$\begin{array}{l}\text { CSR-related } \\
\text { Activities } \\
\text { towards } \\
\text { Suppliers }\end{array}$} & $\begin{array}{l}\text { Guidelines } \\
\text { (95 codings) }\end{array}$ & $\begin{array}{l}\text { "The BMW Group demands compliance with social and ecological standards of its } \\
\text { suppliers too." (BMW 2006) }\end{array}$ \\
\hline & $\begin{array}{l}\text { Others } \\
(27 \text { codings })\end{array}$ & $\begin{array}{l}\text { „...in 2002, the Volkswagen Group Award was awarded to selected suppliers for the first } \\
\text { time. With this award, Volkswagen honored the best suppliers in the categories business } \\
\text { performance, quality, environmental protection, logistics and development.“ (VW 2002) }\end{array}$ \\
\hline \multirow{2}{*}{$\begin{array}{l}\text { CSR-related } \\
\text { Activities } \\
\text { towards Society }\end{array}$} & $\begin{array}{l}\text { CSR-related Reports } \\
\text { (193 codings) }\end{array}$ & $\begin{array}{l}\text { "In } 2006 \text {, for the first time, DaimlerChrysler published an integrated sustainability report } \\
\text { under the title } 360 \text { GRAD «." (Daimler 2007) }\end{array}$ \\
\hline & $\begin{array}{l}\text { Neighborhood } \\
\text { Projects (43 } \\
\text { codings) }\end{array}$ & $\begin{array}{l}\text { "With our neighborly help - Good Neighbors, Good Citizen - the DaimlerChrysler Fund } \\
\text { and our employees contribute to the stability of the community since 1953." (Daimler } \\
\text { 2007) }\end{array}$ \\
\hline \multirow{4}{*}{$\begin{array}{l}\text { Corporate } \\
\text { Donations, } \\
\text { Sponsoring and } \\
\text { Charitables } \\
\text { (in sum: } 768 \\
\text { codings) }\end{array}$} & $\begin{array}{l}\text { Education and } \\
\text { Research }\end{array}$ & $\begin{array}{l}\text { "The focus of the commitment is on supporting disadvantaged children and teenagers." } \\
\text { (TUI 2005) }\end{array}$ \\
\hline & $\begin{array}{l}\text { Sports and } \\
\text { Culture }\end{array}$ & $\begin{array}{l}\text { "Support programs for future conductors, dramatic advisors and directors from the } \\
\text { music theater, support of } 15 \text { yearly scholarship holders..." (Deutsche Bank 2001) }\end{array}$ \\
\hline & Social Issues & $\begin{array}{l}\text { "...the foundation is committed to help people in risk situations and to improve their life } \\
\text { situation..." (Münchner Rück 2007) }\end{array}$ \\
\hline & $\begin{array}{l}\text { Environmental } \\
\text { Issues }\end{array}$ & $\begin{array}{l}\text { "Besides large projects, the Alianz environmental foundation also supports smaller } \\
\text { projects." (Allianz 1998) }\end{array}$ \\
\hline \multirow[t]{2}{*}{$\begin{array}{l}\text { CSR-related } \\
\text { Coope-rations }\end{array}$} & $\begin{array}{l}\text { With other } \\
\text { Companies } \\
\text { (106 codings) }\end{array}$ & $\begin{array}{l}\text { "Together with eight further companies, BASF is founding a knowledge factory. Its two } \\
\text { main areas are education and the support of business start-ups. "(BASF 2005) }\end{array}$ \\
\hline & $\begin{array}{l}\text { With Non-Profit } \\
\text { Organisations } \\
\text { (391 codings) }\end{array}$ & $\begin{array}{l}\text { "As an active member of the UNEP (United Nations Environment Programme), the } \\
\text { World Business Council for Sustainable Development and other important associations, } \\
\text { we take up new insights in the area of sustainable development and integrate them into } \\
\text { our own sustainability concept." (Deutsche Bank 2001) }\end{array}$ \\
\hline \multirow[t]{2}{*}{$\begin{array}{l}\text { Commen- } \\
\text { dations }\end{array}$} & $\begin{array}{l}\text { CSR-related Awards } \\
\text { (165 codings) }\end{array}$ & $\begin{array}{l}\text { "In June 2002, ThyssenKrupp received the Federation of German Industry Award for the } \\
\text { Environment in the category environmentally-friendly technologies." (ThyssenKrupp } \\
\text { 2002) }\end{array}$ \\
\hline & $\begin{array}{l}\text { CSR-related Indices } \\
\text { ( } 243 \text { codings) }\end{array}$ & $\begin{array}{l}\text { "E.ON will be included in the most important index for sustainable companies, the Dow } \\
\text { Jones Sustainability Index (DJSI) and as a result will be even more attractive for } \\
\text { investors who emphasize social responsibility." (Eon 2007) }\end{array}$ \\
\hline
\end{tabular}

Table 3. Coding Scheme 


\begin{tabular}{|ll|}
\hline - & All statements must be specifically stated; they cannot be implied. \\
\hline - & $\begin{array}{l}\text { If any sentence has more than one possible classification, more than one code is } \\
\text { to be allocated. }\end{array}$ \\
\hline - & $\begin{array}{l}\text { Statements relating to the quality of goods or services are not coded unless they } \\
\text { contain a direct relation to social or environmental improvements. }\end{array}$ \\
\hline - & $\begin{array}{l}\text { Statements relating to HRM practice, such as further training and education } \\
\text { corporate pension plans, appraisal interviews and so on that is not CSR-related, } \\
\text { are not to be coded. }\end{array}$ \\
\hline - & $\begin{array}{l}\text { No activities that are based on legal requirements, such as the prevention of } \\
\text { accidents or health prevention, are to be coded. }\end{array}$ \\
\hline - & $\begin{array}{l}\text { Acvitities that are best attributed as graduate recruiting or campus marketing are } \\
\text { not to be coded. }\end{array}$ \\
\hline - & Actitivites that are pure R \& D with no relation to CSR are not to be coded. \\
\hline - & $\begin{array}{l}\text { Codes assigned to the category Sports focus only on amateur sports and not on } \\
\text { professional sponsorship }\end{array}$ \\
\hline
\end{tabular}

Table 4. Decision rules for Coding

Based on the rule that a theme which is more frequently mentioned in the reports is weighted more highly, all of the codes were summed up. Therefore, it is assumed that the significance of a disclosure can be meaningfully represented by its quantity. Consequently, the relative weight and importance of different categories identified by the content analysis was evaluated by the frequency of codes in all annual reports (e.g., Campbell et al. 2006). Some researchers have weighted their codes (e.g., Beck et al. 2010); however, when dealing with longitudinal data, Campbell et al. (2006) found frequency to be the most powerful measure. In our study, some codes initially assigned seemed to capture not only CSR-related topics but also those that appeared to be mostly economically motivated, such as college marketing. As a consequence, only when the text was considered to contain a substantial CSR-related motivation beyond an economical one was it included (see Table 4). The first two categories of the overall coding scheme and code frequencies for all annual reports from 1998 to 2009 are presented in Table 3. In total, eight main categories were identified:

(1) Stated CSR-related philosophy, including statements that depict the philosophy towards CSR or "the range of business responsibilities" (Carroll, 1991: 40) and refer to codes for a) economic and b) judicial responsibility as prerequisites for the existence of the company and c) ethical responsibility, which addresses social and environmental values and norms of the society that the company is embedded in. For our analysis, we drew on the ethical responsibility and coded only statements that comprise a commitment to social or environmental responsibility.

(2) CSR-related motives addressing the reasons why companies engage in CSR with three subcategories: a) performance-driven motives, which are mainly economically oriented and based on profitability, b) stakeholder-driven motives, which acknowledge the importance of stakeholders for the company, and c) value-driven motives, which refer to the ethical responsibilities of the business.

(3) CSR-related internal activities including a) organisational activities (i.e., CSR- related positions, codices, and certified management systems), b) activities in production (i.e., efficient production processes and environmentally friendly or ethical products), and c) activities in human resource management (i.e., CSR-related training, education, and volunteering programs, diversity management, employee suggestion systems).

(4) CSR-related activities with regard to suppliers, referring to a) CSR-related guidelines like minimum requirements for environmental and work-related issues that their suppliers have to comply with or b) other CSR-related activities to provide a constant and lively exchange of knowledge, such as by joint seminars or workshops. 
(5) CSR-related activities towards society, such as a) specific CSR-related reports or websites and b) neighbourhood projects to organise initiatives for community welfare, education and job search, mostly in the region where companies are located.

(6) Corporate Giving, encompassing donations to education and research, sports, culture, social and environmental issues. The category consists mostly of activities focusing on disadvantaged teenagers, which are supported by various educational projects, but scholarships were also coded.

(7) CSR-related Cooperation, Corporate Donations, and Sponsoring related to both forprofit and non-profit organisations, such as cooperation with supranational organisations like UNICEF or the UNEP (United Nations Environment Program) to comply with certain environmental or social guidelines, or cooperation with universities to develop responsible products or production processes or to support education and research.

(8) Awards the company has received for its CSR-activities as well as CSR-related indices on which the company is listed (e.g., the Domini 400 Social Index or the Dow Jones Sustainability Index).

Based on this coding scheme, we used the variables of the final categories and subcategories as described above in the longitudinal analysis. Thus, the content analysis contributed to the quantitative analyses, as it translated the raw data into numbers that were then applied to discover changes over time.

\subsection{Step 2: Longitudinal analysis of CSR-related codings}

Only a fraction of past studies are based on longitudinal data, in which annual reports from more than one year are analysed, thus aiming to uncover trends in CSR reporting () (Abbott and Monsen 1979; Campbell 2004; Cho/Patten 2007; Deegan/Gordon 1996; Campbell 2004; Campbell et al. 2006; Cormier et al. 2005; Gray et al. 1995).

The comparison of the means of CSR-related motives and philosophies stated in the annual reports from a longitudinal perspective spanning the years 1998 to 2009, revealed the following trends as illustrated in Figure 2.

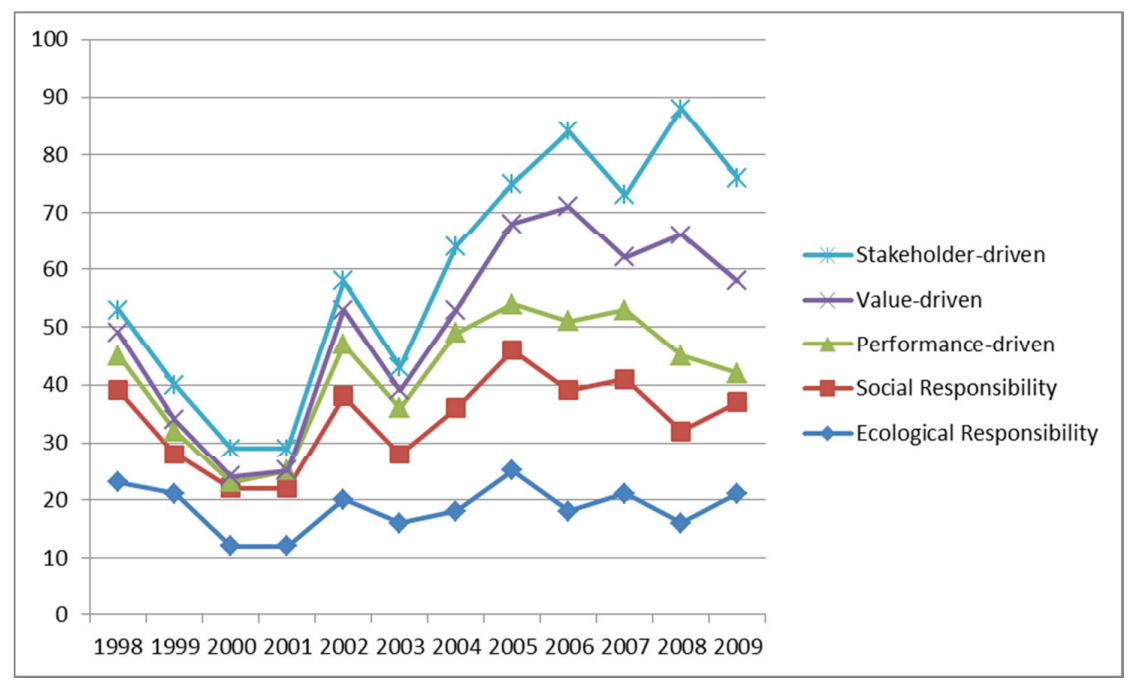

Figure 2. Codes for CSR Philosophy and CSR Motives

The codings for social and environmental CSR-Philosophy remain more or less stable over time, but there is a rise in stated stakeholder and value-driven motives, which can be interpreted. As the latter concentrate more on stakeholder requirements and the ethical responsibilities of companies as compared to performance-driven motives that argue from a pure eco- 
nomic base, a shift in philosophy can be detected; at least in stated philosophy. In the year 2000, a drop for both CSR motives and philosophies can be detected, as well as a smaller drop for motives in 2009. The drop in 2000 can be attributed to the economic crisis following the burst of the dot com bubble in March 2000. However, the question, why the drop in 2009 was smaller than in 2000, remains. One could argue that this is a sign of a rising sincerity in CSR reporting in companies, as they do not forget all there social and environmental responsibilities as crisis strikes. Nevertheless, there is a significant drop in reported CSR activities as Figure 3 shows.

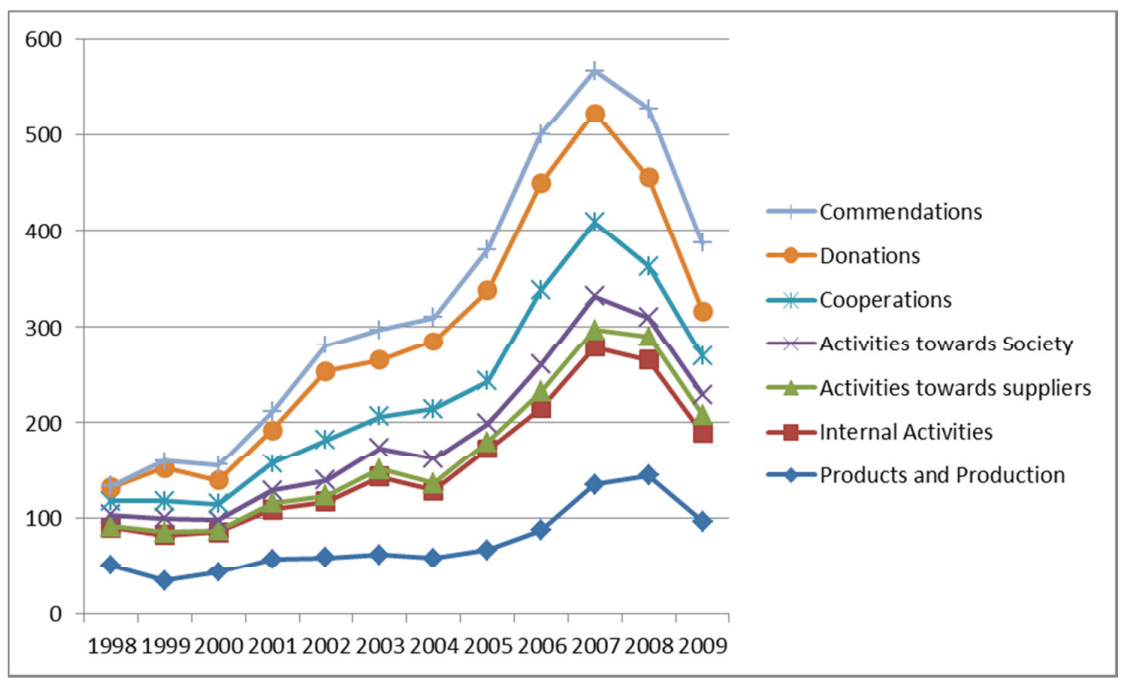

Figure 3. Codes for CSR Activities and Commendations

Overall the codings for CSR-related activities are rising steadily in a similar pattern. However, in 2008 and 2009 all codings are falling. Obviously the reporting of CSR related activities is not so important anymore in times of crisis. Commendations were interpreted as CSR outcomes in our conceptual model (see Figure 1). It is interesting that there is a sharp drop in commendations in the years 2008 and 2009, similar to the drop in CSR-related activities. In general, with regard to both CSR-related motives and activities, the longitudinal analysis of trends in CSR reporting reflects the growing importance of CSR in the stakeholder dialogue over time. Starting from 1998, the aggregated number of CSR-related statements in the annual reports has been increasing, with the highest ratings in activities in the context of production, cooperation, the community, and the organisation as the most important aspects. In relation to CSR-related motives, the results show evidence for a paradigm shift over time, from primarily performance-driven motives for engaging in CSR to the increasing significance of stakeholderdriven and value-driven motives. Regarding all aspects in 2008 and 2009, there is a significant drop in the number and extent of CSR-related coding. Along with existing research insights (e.g., Njoroge 2009; Karaibrahimoglu 2010), a financial crisis results in reduced CSR budgets as well as the postponement or cancellation of social and ecological projects. This creates a dilemma, because to cope with the financial and economic downturn, organisations need to focus on meeting society's needs (Wilson 2008).

\section{Contributions and research implications}

The primary goal of this paper was to examine CSR from a company's point of view and to analyse annual reports with reference to corporate environmental and social disclosures. Based on a sample including the annual reports of all German DAX-30 companies from 1998 to 2009, we specifically concentrated on the question of whether CSR statements are mere hypocrisy 
or sincere actions that are normatively embedded within the overall CSR mission. Voluntary social and environmental reporting has been subject to criticism from scholars who have found them "often partial, incomplete, and self-serving public relations exercises that seek organizational legitimacy through appearance rather than changed behavior" (Kuruppu/Milne 2010), or, simply put, "greenwashing" (Greer/Bruno 1996). Our results give evidence supporting the idea that, along with the public's increased demand for businesses to operate responsibly, in contrast to primarily performance- driven motives, there has been a rising significance of stakeholderdriven and value-driven motives as a normative basis for engaging in CSR. This research is based on qualitative data, and it can be argued that content analysis in particular lacks reliability and validity as an interpretative means of analysis. However, as Deegan/Gordon (1996) have pointed out, these difficulties are more significant when a rather small sample of documents is examined. In our study, we have examined a quite large sample and therefore conclude that the overall measurement error is negligible. Furthermore, one of our study's main aims, extracting a more meaningful CSR-related category scheme from annual reports and depicting longitudinal trends in CSR reporting, does not rely on a precise measurement.

Overall, with a combination of qualitative and quantitative analyses, this paper builds upon and extends past research efforts in the field of CSR and CSR reporting, as it provides deeper insights into qualitative, longitudinal, and quantifiable effects encompassing a rich category scheme that also accounts for the stated CSR-related philosophy and motives to engage in CSR, related to different fields of CSR activities.

Although our results are only initial empirical hints, they should be explored in further research in different ways. Because the national culture of the reporting company is considered a determinant of CSR reporting (e.g., van der Laan Smith et al. 2005; Aerts et al. 2008), a study comparing different countries may lead to interesting results regarding differences and similarities in the definition and communication of CSR. Besides, in our analyses, we did not separate home-market activities from international activities of the companies - given their multinational activities, there might be differences in their CSR commitment in international markets or production sites. In general, the question of how CSR adds value to the actual performance of the company, based on interviews with stakeholder groups or expert judgments on firm philosophy, motives, and activities, possible causal relations between CSR and outcomes such as, for example, corporate reputation, could be examined.

\section{References}

Abbott, W.F./Monsen, R.J. 1979: “On the Measurement of Corporate Social Responsibility: Self- Reported Disclosures as a Method of Measuring Corporate Social Involvement". In Academy of Management Journal, Vol. 22, No. 3, 501-515.

Adams, C.A./Hill, W./Roberts, C.B. 1998: "Corporate Social Reporting Practices in Western Europe: Legitimizing Corporate Behavior?”. In British Accounting Review, Vol. 30, No. 1, 1-21.

Aerts, W./Cormier, D./ Magnan, M. 2008: "Corporate Environmental Disclosure, Financial Markets and the Media: An International Perspective”. In Ecological Economics, Vol. 64, No. 3, 643-659.

Amaeshi, K.M./Ogbechie, C./Adi, B.C./Amao, O.O. 2006: “Corporate Social Responsibility in Nigeria: Western Mimicry or Indigenous Influences?”. In Journal of Corporate Citizenship, Vol. 24, 83-99.

Anselmsson, J./ Johansson, U. 2007: "Corporate Social Responsibility and the Positioning of Grocery Brands: An Exploratory Study of Retailer and Manufacturer Brands at Point of Purchase". In International Journal of Retail \& Distribution Management, Vol. 35, No. 10, 835-856.

Balsam, S./Bartov, E./Marquardt, C. 2002: “Accruals Management, Investor Sophistication, and Equity Valuation: Evidence from 10-Q Filings". In Journal of Accounting Research, Vol. 40, No. 4, 987-1012.

Beck, A.C./Campbell, D./Shrives, P.J. 2010: "Content Analysis in Environmental Reporting Research: Enrichment and Rehearsal of the Method in a British-German Context”. In The British Accounting Review, Vol. 42, No. 3, 207-222.

Bhattacharya, C.B./Sen, S. 2003: “Consumer-Company Identification: A Framework for Understanding Consumers' Relationships with Companies”. In Journal of Marketing, Vol. 67, No. 2, 76-88. 
Brammer, S./ Pavelin, S. 2008: "Factors Influencing the Quality of Corporate Environmental Disclosure". In Business Strategy and the Environment, Vol. 17, No. 2, 120-136.

Calabrese, A./Lancioni, F. 2008: "Analysis of Corporate Social Responsibility in the Service Sector: Does Exist a Strategic Path". In The Official Journal of the Institute of Business Re-engineering, Vol. 15, No. 2, 107-125.

Campbell, D.A. 2004: "A Longitudinal and Cross-Sectional Analysis of Environmental Disclosure in UK Companies - A Research Note”. In The British Accounting Review, Vol. 36, No. 1, 107-117.

Campbell, D.J./Beck, C./Shrives, P. 2004: "The Information Content of Environmental Disclosures in UK and German Companies Annual Reports"; paper presented at Fourth Asia Pacific Interdisciplinary Research in Accounting Conference, 4- 6 July 2004, Singapore [online]. http://www.smu.edu.sg/events/apira/2004/Final\%20 Papers/1174-campbell.pdf (accessed 13 December 2010).

Campbell, D./Moore, G./Shrives, P. 2006: "Cross-Sectional Effects in Community Disclosure". In Accounting, Auditing \& Accountability Journal, Vol. 19, No. 1, 96-114.

Carroll, A.B. 1979: “A Three-Dimensional Conceptual Model of Corporate Performance”. In The Academy of Management Review, Vol. 4, No. 4, 479-505.

Carroll, A.B. 1991: "The Pyramid of Corporate Social Responsibility: Toward the Moral Management of Organizational Stakeholders". In Business Horizons, Vol. 34, No. 4, 39-48.

Chen, S./Bouvain, P. 2009: "Is Corporate Responsibility Converging? A Comparison of Corporate Responsibility Reporting in the USA, UK, Australia, and Germany". In Journal of Business Ethics, Vol. 87, No. 1, 299-317.

Cho, C.H./Patten, D.M. 2007: "The Role of Environmental Disclosures as Tools of Legitimacy: A Research Note". In Accounting, Organizations and Society, Vol. 32, No. 7-8, 639-647.

Cormier, D./Magnan, M./van Velthoven, B. 2005: "Environmental Disclosure Quality in Large German Companies: Economic Incentives, Public Pressures or Institutional Conditions?”. In European Accounting Review, Vol. 14, No. 1, 3-39.

Deegan, C./Gordon, B. 1996: "A Study of The Environmental Disclosure Policies of Australian Corporations". In Accounting and Business Research, Vol. 26, No. 3, 187-99.

Dowling, J./ Pfeffer, J. 1975: “Organisational Legitimacy, Social Values and Organizational Behavior”. In Pacific Sociological Review, Vol. 18, No. 6, 12-36.

Drumwright, M.E. 1994: "Socially Responsible Organizational Buying: Environmental Concern as a Noneconomic Buying Criterion”. In Journal of Marketing, Vol. 58, No. 3, 1-19.

Ernst and Ernst 1978: Social Responsibility Disclosure, 1978 Survey. Ernst and Ernst, Cleveland.

European Commission 2001: Green Paper: Promoting a European framework for Corporate Social Responsibility, European Commission, Brussels.

Gray, R./Kouhy, R./ Lavers, S. 1995: "Corporate Social and Environmental Reporting: A Review of the Literature and a Longitudinal Study of UK Disclosure". In Accounting, Auditing \& Accountability Journal, Vol. 8, No. 2, 47-77.

Greer, J./Bruno, K. 1996: Greenwash: The Reality Behind Corporate Environmentalism. Third World Network, Penang.

Gupta, S./Pirsch, J. 2008: "The Influence of a Retailer's Corporate Social Responsibility Program on Re-Conceptualizing Store Image”. In Journal of Retailing and Consumer Service, Vol. 15, No. 6, 516-526.

Hackston, D./Milne, M.J. 1996: "Some Determinants of Social and Environmental Disclosures in New Zealand Companies”. In Accounting, Auditing \& Accountability Journal, Vol. 9, No. 1, 77-108.

Hasseldine, J./Salama, A./Toms, S. 2005: "Quantity Versus Quality: The Impact of Environmental Disclosures on the Reputations of UK PLCs”. In The British Accounting Review, Vol. 37, No. 2, 231-248.

Hope, O./Pope, P.F. 2003: "Disclosure Practices, Enforcement of Accounting Standards, and Analysts' Forecast Accuracy: An International Study”. In Journal of Accounting Research, Vol. 41, No. 2, 235-272.

Ibrahim, N.A./Howard, D.P./Angelidis, J.P. 2003: "Board Members in the Service Industry: An Empirical Examination of the Relationship Between Corporate Social Responsibility Orientation an Directorial Type". In Journal of Business Ethics, Vol. 47, No. 4, 393-401.

Idowu, S.O./Papasolomou, I. 2007: "Are the Corporate Social Responsibility Matters Based on Good Intentions or False Pretences: An Empirical Study of the Motivations Behind the Issuing of CSR Reports by UK Companies". In The International Journal of Effective Board Performance, Vol. 7, No. 2, 136-147.

Ingram, R.W./ Frazier, K.B. 1980: "Environmental Performance and Corporate Disclosure". In Journal of Accounting Research, Vol. 18, No. 2, 614-622. 
Jamali, D./Mirshak, R. 2007: "Corporate Social Responsibility (CSR): Theory and Practice in a Developing Country Context”. In Journal of Business Ethics, Vol. 72, No. 3, 243-262.

Jones, T.M. 1995: "Instrumental Stakeholder Theory: A Synthesis of Ethics and Economics". In Academy of Management Review, Vol. 20, No. 2, 404-437.

Karaibrahimoglu, Y.Z. 2010: "Corporate Social Responsibility in Times of Financial Crisis". In African Journal of Business Management, Vol. 4, No. 4, 382-389.

Krippendorf, K. 2003: Content Analysis: An Introduction to its Methodology, Sage, Beverly Hills.

Kuruppu, S./Milne, M.J. 2010: “Dolphin Deaths, Organizational Legitimacy and Potential Employees' Reactions to Assured Environmental Disclosures”. In Accounting Forum, Vol. 34 No. 1, 1-19.

Lee, T.M./Hutchison, P.D. 2005: "The Decision to Disclose Environmental Information: A Research Review and Agenda". In Reckers, P.M.J. (ed.), Advances in Accounting, Vol. 21. Elsevier, Oxford, 83-111.

Lougee, B.A./Wallace, J.S. 2008: “The Corporate Social Responsibility (CSR) Trend”. In Journal of Applied Corporate Finance, Vol. 20, No. 1, 96-108.

Macleod, S. 2001: ”Why worry about CSR?”. In Strategic Communication Management, Vol. 5, No. 5, 8-9.

Maignan, I./ Ralston, D.A. 2002: "Corporate Social Responsibility in Europe and the U.S.: Insights from Business Self-presentations”. In Journal of Business Studies, Vol. 33, No. 3, 497-514.

Milne, M.J./Adler, R.W. 1999: "Exploring the Reliability of Social and Environmental Disclosures Content Analysis". In Accounting, Auditing \& Accountability Journal, Vol. 12, No. 2, 237-256.

Neu, D./Warsame, H./Pedwell, K. 1998: "Managing Public Impressions: Environmental Disclosures in Annual Reports". In Accounting, Organizations and Society, Vol. 23, No. 3, 265-282.

Njoroge, J. 2009: "Effects of the Global Financial Crisis on Corporate Social Responsibility in Multinational Companies in Kenya"; Covalence Intern Analyst Papers [online]. http://www.covalence.ch/docs/Kenya-Crisis.pdf (accessed 8 January 2011).

Orlitzky, M./Schmidt, F.L./Rynes, S.L. 2003: “Corporate Social and Financial Performance: A Meta-Analysis”. In Organization Studies, Vol. 24, No. 3, 403-441.

Patten, D.M. 2002: "The Relation Between Environmental Performance and Environmental Disclosure: A Research Note". In Accounting, Organizations and Society, Vol. 27, No. 8, 763-773.

Perrini, F./Russo, A./Tencati, A. 2007: "CSR Strategies of SMEs and Large Firms: Evidence from Italy". In Journal of Business Ethics, Vol. 74, No. 3, 285-300.

Pedersen, E.R. 2009: "The Many and the Few: Rounding Up the SMEs that Manage CSR in the Supply Chain". In Supply Chain Management: An International Journal, Vol. 14, No. 2, 109-116.

Pomering, A./Dolnicar, S. 2007: "Consumer Response to Corporate Social Responsibility Initiatives: An Investigation of Two Necessary Awareness States", University of Wollongong - Faculty of Commerce [online]. http:// ro.uow.edu.au/commpapers/422 (accessed 13 December 2010).

Porter, M.E./ Kramer, M.R. 2002: “The Competitive Advantage of Corporate Philanthropy”. In Harvard Business Review, Vol. 80, No. 12, 5-16.

Russo, A./Tencati, A. 2009: "Formal vs. Informal CSR Strategies: Evidence from Italian Micro, Small, MediumSized, and Large Firms". In Journal of Business Ethics, Vol. 85, No. 2, 339-353.

Schocker, A.D./Sethi, S.P. 1974: "An Approach to Incorporating Social Preferences in Developing Corporate Action Strategies”. In Sethi, S.P. (ed.), The Unstable Ground: Corporate Social Policy in a Dynamic Society. Los Angeles: John Wiley \& Sons, 76-80.

Siegel, D.S./Vitaliano, D.F. 2007: “An Empirical Analysis of Strategic Use of Corporate Social Responsibility”. In Journal of Economics \& Management Strategy, Vol. 16, No. 3, 773-792.

Singh, J./Sanchez, M./Rodriguez, I. 2008: "Understanding Corporate Social Responsibility and Product Perceptions in Consumer Markets: A Cross-cultural Evaluation". In Journal of Business Ethics, Vol. 80, No. 3, 597-611.

Srnka, K./Koeszegi, S. 2007: "From Words to Numbers: How to Transform Qualitative Data into Meaningful Quantitative Results". In Schmalenbach's Business Review, Vol. 59, No. 1, 29-57.

Turker, D. 2009: "Measuring Corporate Social Responsibility: A Scale Development Study". In Journal of Business Ethics, Vol. 85, No. 4, 411-427.

Van der Laan Smith, J., Adhikari, A./Tondkar, R.H. 2005: "Exploring Differences in Social Disclosures Internationally: A Stakeholder Perspective”. In Journal of Accounting and Public Policy, Vol. 24, No. 2, 123-151.

van Staden, C.J./Hooks, J. 2007: “A Comprehensive Comparison of Corporate Environmental Reporting and responsiveness”. In The British Accounting Review, Vol. 39, No. 3, 197-210. 
Vlachos, P.A./Tsamakos, A./Vrechopoulos, A.P./Avramidis, P.K. 2009: "Corporate Social Responsibility: Attributions, Loyalty, and the Mediating Role of Trust”. In Journal of the Academy of Marketing Science, Vol. 37, No. 2, 170-180.

Wilson, A. 2008: "Deepening Financial Crisis Should not Derail Corporate Social Responsibility”, Special to Kyiv Post [online]. http://www.kyivpost.com/business/bus_focus/30379 (accessed 8 January 2011). 
